\title{
Prevalence of primary cardiac tumor malignancies in retrospective studies over six decades: a systematic review and meta-analysis
}

\author{
Shuai He ${ }^{1}$, Yide Cao ${ }^{1}$, Wei Qin ${ }^{1}$, Wen Chen ${ }^{1}$, Li Yin ${ }^{1}$, Hao Chai ${ }^{1}$, Zhonghao Tao ${ }^{1}$, \\ Shaowen Tang ${ }^{2}$, Zhibing Qiu ${ }^{1}$ and Xin Chen ${ }^{1}$ \\ ${ }^{1}$ Department of Thoracic and Cardiovascular Surgery, Nanjing First Hospital, Nanjing Medical University, Nanjing, Jiangsu, \\ China \\ ${ }^{2}$ Department of Epidemiology, School of Public Health, Nanjing Medical University, Nanjing, Jiangsu, China \\ Correspondence to: Xin Chen, email: stevecx1@163.com \\ Zhibing Qiu, email: qiuzhibing2009@163.com \\ Keywords: prevalence, malignancy, primary cardiac tumors, retrospective studies, meta-analysis \\ Abbreviations: PMCTs: primary malignant cardiac tumors; PCTs: primary cardiac tumors; SEER: Surveillance, Epidemiology and End \\ Results; MRI: magnetic resonance imaging; MDCT: multi-detector computerized tomography \\ Received: November 30, $2016 \quad$ Accepted: March 30, $2017 \quad$ Published: April 24, 2017
}

Copyright: He et al. This is an open-access article distributed under the terms of the Creative Commons Attribution License 3.0 (CC BY 3.0), which permits unrestricted use, distribution, and reproduction in any medium, provided the original author and source are credited.

\section{ABSTRACT}

The incidence of patients diagnosed with primary malignant cardiac tumors (PMCTs) has increased greatly in the past few decades. Whether this rising prevalence is due to overdiagnosis or an increased malignancy rate of primary cardiac tumors (PCTs) remains unclear. Therefore, we performed a systematic review and meta-analysis of published retrospective studies to determine whether the malignancy rate has been increasing over time. Published studies containing relevant data between 1956 and 2014 were evaluated. Two authors searched for all retrospective studies that included patients diagnosed with PCT and PMCT. Two other investigators independently extracted the data, and discrepancies were resolved by consensus. A random-effects meta-analysis model and cumulative meta-analysis model were used to evaluate the pooled prevalence and trend of dynamic change in PCT malignancies. The effects of time, study period and sample size were studied using a logit-linear regression model with robust error variance and a time variable. Thirty-eight studies involving 5,586 patients were analyzed. The pooled prevalence of PMCT among the patients diagnosed with PCT was 9.9\% (95\% CI, 8.4\% to $11.4 \%)\left(I^{2}=70 \% ; P<0.001\right)$, and this prevalence has been stable since around 2003. In the regression model, the malignancy odds ratio remained stable from 1975 onward, and no time effect was observed. Our study confirms that PMCT is uncommon, and the prevalence of PCT malignancies remained stable in the past few decades. The clinically observed increase in incidence is unlikely to reflect a true population-level increase in tumorigenesis. This result strongly suggests that the observed increase in incidence of PMCT most likely reflects increased diagnostic detection over time.

\section{INTRODUCTION}

Primary malignancies of the heart are extremely rare, and poor prognosis continues to challenge the diagnostic ability and surgical skill of clinicians [1-4]. According to the WHO Histological Classification of Tumors of the Heart and Pericardium, the majority of the malignant primary tumors of the heart can be categorized as various types of sarcomas, with primary cardiac lymphoma and epithelioid hemangioendothelioma accounting for a small fraction of cases [5]. The core knowledge of PMCTs is based mostly on case reports and autopsy studies due to their limited incidence and the difficulty of early diagnosis [6]. Because of the relatively small numbers and the significant referral bias of these studies, in October 2015, Oliveira and AlKindi [7] queried the largest cancer registry (Surveillance, Epidemiology and End Results, SEER) in the United States for all PMCTs diagnosed (>500 Patients) from 1973 to 2011 and found an increased incidence and survival of patients diagnosed with PMCT over the past 5 decades. A recent study in Italy (1998-2011) estimated the incidence of PMCTs at $\approx 130$ per 100 million persons [8]. Whether this prevalence 
is a result of overdiagnosis or an increased malignancy rate of primary cardiac tumors (PCTs) is unclear. Pooling these data over similar time periods would allow for a determination of whether the malignancy rate has changed over time.

With advances in electronic imaging technology, the integrated use of cardiac imaging tools such as transthoracic or trans-esophageal echocardiography, magnetic resonance imaging (MRI) and multi-detector computerized tomography (MDCT) has become important during the diagnostic procedure [5]. These methods allow the rapid acquisition of real-time heart images with high spatial and temporal resolution and excellent characterization of the tumor tissue [9-11]. However, clinical manifestations of primary malignancies of the heart are so variable that their discovery may still be incidental during surgery or autopsy [12]. Although cardiac imaging tools are widely used and very important for clinical decision-making and surgical programs, as with other malignancies, histopathological examination is still indispensable and irreplaceable. To our knowledge, primary malignant cardiac tumors are asymptomatic until they reach significant dimensions [13], and the clinical symptoms (dyspnea, syncope, pain, arrhythmias, constitutional symptoms, and heart failure) are usually dependent on tumor size, invasiveness, friability, rate of growth, and especially, its location in the heart $[14,15]$.
We sought to better understand PMCTs, using retrospective studies from surgical centers around the world to investigate the prevalence of primary cardiac tumor malignancies over the past few decades.

\section{RESULTS}

\section{Study}

We identified 636 unique publications that met the initial search criteria. The titles and abstracts were screened for inclusion. The full texts of 72 articles were retrieved, and 38 studies involving a total of 5,586 patients from 1956 to 2014 were selected and included in the final analysis (Figure 1). Characteristics of the excluded studies are listed in Table 1. Among the 38 studies, there was one registry analysis (Surveillance Epidemiology and End Results database) [7], two multicenter analyses [2, 16] and 35 single surgical center series. Twenty-seven studies performed survival analyses, and we collected the clinical outcome after surgical resection for PMCTs, which remains universally poor. The mean age of patients diagnosed with PMCTs ranged from 35.8 to 68 years of age, and $52.1 \%$ of patients were female, according to the available data. For purposes of comparing studies from different periods, we used the median year of each of the following periods when the studies were performed: before 1975 in three data sets [17-19]; between 1975 and

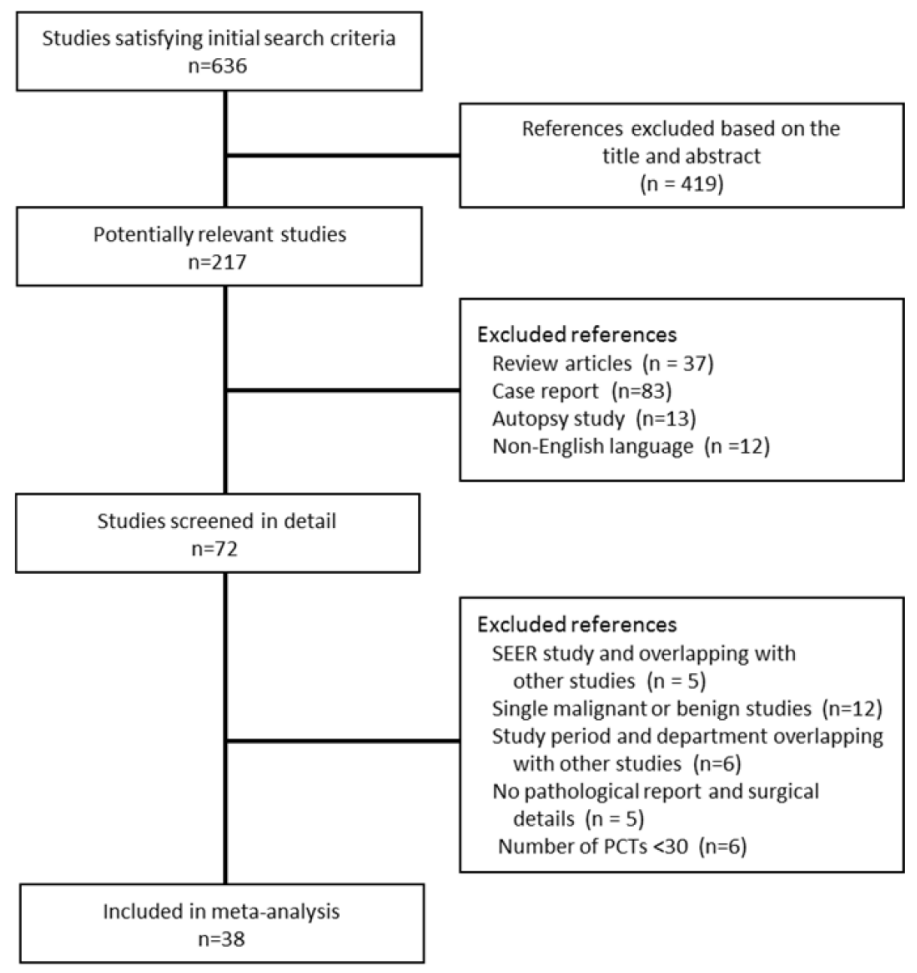

Figure 1: Flow diagram of study selection. 
Table 1: Characteristics of eligible studies

\begin{tabular}{|c|c|c|c|c|c|c|c|c|}
\hline \multirow[t]{2}{*}{ Author and year } & \multirow[t]{2}{*}{ Country } & \multirow{2}{*}{$\begin{array}{l}\text { Study period } \\
\text { / median } \\
\text { year of study } \\
\text { period }\end{array}$} & \multicolumn{3}{|c|}{ Patients diagnosed with pmct } & \multirow{2}{*}{$\begin{array}{c}\text { No. Of } \\
\text { patients } \\
\text { diagnosed } \\
\text { with pet }\end{array}$} & \multirow{2}{*}{$\begin{array}{c}\text { Malignancy } \\
\text { rate of pet (\%) }\end{array}$} & \multirow{2}{*}{$\begin{array}{l}\text { Surgical } \\
\text { outcome }\end{array}$} \\
\hline & & & $\begin{array}{c}\text { Mean } \\
\text { age } \\
\text { (years) }\end{array}$ & Female(\%) & Number & & & \\
\hline Toshiaki, 2016 & Japan & $\begin{array}{c}2010- \\
2013 / 2012\end{array}$ & 68 & 57 & 113 & 1317 & 8.6 & NA \\
\hline Andreas, 2015 & Austria & $\begin{array}{c}1999- \\
2014 / 2006\end{array}$ & 48.8 & 45.5 & 11 & 113 & 9.7 & $\begin{array}{l}\text { Late mortality } \\
(>30 \mathrm{~d}): 63.3 \%\end{array}$ \\
\hline Barreiro, 2013 & Spain & $\begin{array}{c}1979- \\
2012 / 1995\end{array}$ & 50 & 45.5 & 11 & 73 & 15.1 & $\begin{array}{c}1 \text {-year mortality } \\
100 \%\end{array}$ \\
\hline Miralles ,1991 & France & $\begin{array}{c}1972- \\
1989 / 1981\end{array}$ & 43.5 & 87.5 & 7 & 73 & 9.6 & $\begin{array}{c}\text { 1-year mortality } \\
57.1 \%\end{array}$ \\
\hline Yu, 2007 & China & $\begin{array}{c}1996- \\
2005 / 2000\end{array}$ & NA & NA & 22 & 234 & 9.4 & NA \\
\hline Qingyi, 2002 & China & $\begin{array}{c}1990- \\
2000 / 1995\end{array}$ & NA & NA & 31 & 149 & 20.8 & NA \\
\hline Yin, 2016 & China & $\begin{array}{c}2008- \\
2013 / 2010\end{array}$ & 51 & 61.5 & 21 & 125 & 16.8 & $\begin{array}{c}\text { 1-year mortality } \\
70 \%\end{array}$ \\
\hline Dell'amore, 2013 & Italy & $\begin{array}{c}1990- \\
2010 / 2000\end{array}$ & 41 & 25 & 4 & 91 & 4.4 & $\begin{array}{c}1 \text {-year mortality } \\
100 \%\end{array}$ \\
\hline Barnes, 2014 & Australia & $\begin{array}{c}1990- \\
2012 / 2001\end{array}$ & 52 & NA & 6 & 30 & 20 & NA \\
\hline Andrew, 2008 & $\begin{array}{l}\text { United } \\
\text { States }\end{array}$ & $\begin{array}{c}1957- \\
2006 / 1982\end{array}$ & 51.42 & 53 & 19 & 323 & 6 & $\begin{array}{c}1 \text {-year mortality } \\
100 \%\end{array}$ \\
\hline Thomas, 2011 & Germany & $\begin{array}{c}2000- \\
2010 / 2005\end{array}$ & NA & NA & 3 & 62 & 4.8 & $\begin{array}{c}\text { 1-year mortality } \\
66.7 \%\end{array}$ \\
\hline Kamiya, 2001 & Japan & $\begin{array}{c}1973- \\
2000 / 1987\end{array}$ & 55.5 & 25 & 4 & 34 & 11.8 & $\begin{array}{c}\text { 1-year mortality } \\
75 \%\end{array}$ \\
\hline Blondeau, 1990 & France & $\begin{array}{c}1961- \\
1988 / 1975\end{array}$ & 46 & NA & 53 & 533 & 9.9 & $\begin{array}{l}\text { Mean survival } \\
1.5 \text { years }\end{array}$ \\
\hline Molina,1990 & $\begin{array}{l}\text { United } \\
\text { States }\end{array}$ & $\begin{array}{c}1959- \\
1989 / 1974\end{array}$ & NA & 47.6 & 21 & 124 & 16.9 & $\begin{array}{c}\text { Mean survival } 5 \\
\text { months }\end{array}$ \\
\hline Murphy,1990 & $\begin{array}{l}\text { United } \\
\text { States }\end{array}$ & $\begin{array}{c}1964- \\
1989 / 1977\end{array}$ & 38 & 41.7 & 12 & 114 & 10.5 & NA \\
\hline Basso,1997 & Italy & $\begin{array}{c}1970- \\
1995 / 1983\end{array}$ & NA & NA & 9 & 114 & 7.9 & NA \\
\hline Centofanti, 1999 & Italy & $\begin{array}{c}1980- \\
1997 / 1989\end{array}$ & 53 & 80 & 5 & 91 & 5.5 & $\begin{array}{c}3 \text {-year mortality } \\
100 \%\end{array}$ \\
\hline Perchinsky,1997 & Canada & $\begin{array}{c}1956- \\
1996 / 1976\end{array}$ & NA & NA & 14 & 71 & 19.7 & NA \\
\hline Tschirkov, 1990 & Bulgaria & $\begin{array}{c}1970- \\
1988 / 1979\end{array}$ & NA & NA & 1 & 63 & 1.6 & NA \\
\hline Moosdoef, 1990 & Germany & $\begin{array}{c}1971- \\
1990 / 1981\end{array}$ & NA & NA & 9 & 51 & 17.6 & $\begin{array}{c}3 \text {-year mortality } \\
50 \%\end{array}$ \\
\hline Dein, 1987 & $\begin{array}{l}\text { United } \\
\text { States }\end{array}$ & $\begin{array}{c}1961- \\
1986 / 1974\end{array}$ & NA & 50 & 8 & 42 & 19 & $\begin{array}{c}\text { 30-days mortality } \\
37.5 \% \\
\text { (Continued) }\end{array}$ \\
\hline
\end{tabular}




\begin{tabular}{|c|c|c|c|c|c|c|c|c|}
\hline \multirow[t]{2}{*}{ Author and year } & \multirow[t]{2}{*}{ Country } & \multirow{2}{*}{$\begin{array}{l}\text { Study period } \\
\text { / median } \\
\text { year of study } \\
\text { period }\end{array}$} & \multicolumn{3}{|c|}{ Patients diagnosed with pmet } & \multirow{2}{*}{$\begin{array}{c}\text { No. Of } \\
\text { patients } \\
\text { diagnosed } \\
\text { with pct }\end{array}$} & \multirow{2}{*}{$\begin{array}{c}\text { Malignancy } \\
\text { rate of pet }(\%)\end{array}$} & \multirow{2}{*}{$\begin{array}{l}\text { Surgical } \\
\text { outcome }\end{array}$} \\
\hline & & & $\begin{array}{c}\text { Mean } \\
\text { age } \\
\text { (years) }\end{array}$ & Female(\%) & Number & & & \\
\hline Grande, 1993 & Italy & $\begin{array}{c}1980- \\
1992 / 1986\end{array}$ & 35.8 & 0 & 5 & 31 & 16.1 & $\begin{array}{c}1 \text {-year mortality } \\
75 \%\end{array}$ \\
\hline Saraiva, 2016 & Portugal & $\begin{array}{c}1994- \\
2014 / 2004\end{array}$ & 55.4 & 66.7 & 12 & 123 & 9.8 & $\begin{array}{c}\text { 1-year mortality } \\
41.7 \%\end{array}$ \\
\hline Ricardo, 2014 & Brazil & $\begin{array}{c}1986- \\
2011 / 1999\end{array}$ & 44.3 & 50 & 12 & 185 & 6.5 & $\begin{array}{c}1 \text {-year mortality } \\
<50 \%\end{array}$ \\
\hline Anna, 2011 & Poland & $\begin{array}{c}1986- \\
2009 / 1998\end{array}$ & NA & NA & 5 & 119 & 4.2 & $\begin{array}{c}1 \text {-year mortality } \\
<20 \%\end{array}$ \\
\hline Massimo, 2012 & Italy & $\begin{array}{c}1990- \\
2005 / 1997\end{array}$ & NA & NA & 6 & 89 & 6.7 & $\begin{array}{c}1 \text {-year mortality } \\
<50 \%\end{array}$ \\
\hline Faisal, 2003 & $\begin{array}{l}\text { United } \\
\text { States }\end{array}$ & $\begin{array}{c}1975- \\
2002 / 1989\end{array}$ & NA & NA & 17 & 85 & 20 & $\begin{array}{c}1 \text {-year mortality } \\
53 \%\end{array}$ \\
\hline Bossert, 2005 & Germany & $\begin{array}{c}1994- \\
2003 / 1998\end{array}$ & 62.7 & 50 & 4 & 77 & 5.2 & $\begin{array}{c}1 \text {-year mortality } \\
50 \%\end{array}$ \\
\hline Patel, 2009 & UK & $\begin{array}{c}1990- \\
2008 / 1999\end{array}$ & NA & NA & 27 & 94 & 28.7 & NA \\
\hline Agarwal, 2003 & India & $\begin{array}{c}1989- \\
2001 / 1995\end{array}$ & NA & NA & 2 & 34 & 5.9 & NA \\
\hline Hoffmeier, 2005 & Germany & $\begin{array}{c}1989- \\
2004 / 1997\end{array}$ & NA & NA & 10 & 94 & 10.6 & $\begin{array}{c}\text { Mean survival } \\
5.5 \text { years }\end{array}$ \\
\hline Dapper,1988 & Germany & $\begin{array}{c}1971- \\
1987 / 1979\end{array}$ & NA & NA & 9 & 48 & 18.7 & $\begin{array}{c}\text { 2-year mortality } \\
88.9 \%\end{array}$ \\
\hline Thomas, 2007 & France & $\begin{array}{c}1986- \\
2005 / 1995\end{array}$ & 38.4 & 50 & 8 & 53 & 15.1 & $\begin{array}{c}1 \text {-year mortality } \\
53 \%\end{array}$ \\
\hline Thiene, 2013 & Italy & $\begin{array}{c}1970- \\
2010 / 1990\end{array}$ & 50 & 42.3 & 26 & 239 & 10.5 & $\begin{array}{c}\text { 1-year mortality } \\
88.5 \%\end{array}$ \\
\hline Agaimy, 2012 & Germany & $\begin{array}{c}1999- \\
2011 / 2005\end{array}$ & 45.6 & 60 & 5 & 74 & 6.7 & $\begin{array}{c}1 \text {-year mortality } \\
40 \%\end{array}$ \\
\hline Carrel, 2011 & Switzerland & $\begin{array}{c}1996- \\
2010 / 2003\end{array}$ & NA & NA & 11 & 155 & 7.1 & $\begin{array}{c}\text { 1-year mortality } \\
36.4 \%\end{array}$ \\
\hline Kumar, 2011 & India & $\begin{array}{c}1995- \\
2010 / 2002\end{array}$ & NA & 28.6 & 14 & 184 & 7.6 & NA \\
\hline Tazelaar,1992 & $\begin{array}{l}\text { United } \\
\text { States }\end{array}$ & $\begin{array}{c}1957- \\
1991 / 1974\end{array}$ & NA & 63.2 & 8 & 106 & 7.5 & NA \\
\hline
\end{tabular}

PCT: primary cardiac tumor; PMCT: primary malignant cardiac tumor.

1980 in five data sets [2, 20-23]; between 1981 and 1985 in four data sets [4, 24-26]; between 1986 and 1990 in five data sets [5, 27-30]; between 1991 and 1995 in four data sets [31-34]; between 1996 and 2000 in eight data sets [35-42]; between 2001 and 2005 in six data sets [43-48]; and after 2005 in 3 data sets $[16,49,50]$ (Table 1).

According to our risk of bias table, the most common deficiencies were the following: the relevant variables in the study populations were not closely representative of the national population; different modes of tumor examination were used in 9 studies; and nonsystematic cancer detection methods were used in 4 studies (Table 2). 
Table 2: Quality assessment of the included studies

\begin{tabular}{|c|c|c|c|c|c|c|c|c|c|}
\hline \multirow{2}{*}{$\begin{array}{l}\text { Author and } \\
\text { year }\end{array}$} & \multicolumn{4}{|c|}{ External Validity } & \multicolumn{5}{|c|}{ Internal Validity } \\
\hline & $\begin{array}{c}\text { Patients } \\
\text { diagnosed } \\
\text { with pct } \\
\text { were a close } \\
\text { representation } \\
\text { of the national } \\
\text { pct patients }\end{array}$ & $\begin{array}{l}\text { Did not } \\
\text { deliberately } \\
\text { restrict the } \\
\text { included } \\
\text { patients in } \\
\text { any way }\end{array}$ & $\begin{array}{l}\text { Unavailable } \\
\text { data }<20 \%\end{array}$ & $\begin{array}{c}\text { No data } \\
\text { duplication }\end{array}$ & $\begin{array}{c}\text { Data } \\
\text { collected } \\
\text { directly } \\
\text { from the } \\
\text { hospital } \\
\text { medical } \\
\text { records } \\
\text { and } \\
\text { surgery } \\
\text { database }\end{array}$ & $\begin{array}{c}\text { An } \\
\text { acceptable } \\
\text { case } \\
\text { definition }\end{array}$ & $\begin{array}{c}\text { Cancer detection } \\
\text { method } \\
\text { was reliable } \\
\text { and valid } \\
\text { (histopathology) }\end{array}$ & $\begin{array}{l}\text { Same mode } \\
\text { oftumor } \\
\text { examination } \\
\text { forall } \\
\text { patients in } \\
\text { the study }\end{array}$ & $\begin{array}{l}\text { Numerator and } \\
\text { denominatormatch } \\
\text { the reported results }\end{array}$ \\
\hline Toshiaki, 2016 & Y & $\mathrm{Y}$ & $\mathrm{N}$ & $\mathrm{Y}$ & Y & $\mathrm{Y}$ & Y & $\mathrm{N}$ & $\mathrm{Y}$ \\
\hline Andreas, 2015 & $\mathrm{~N}$ & $\mathrm{Y}$ & $\mathrm{Y}$ & $\mathrm{Y}$ & $\mathrm{Y}$ & $\mathrm{Y}$ & $\mathrm{Y}$ & $\mathrm{Y}$ & $\mathrm{Y}$ \\
\hline Barreiro, 2013 & $\mathrm{~N}$ & $\mathrm{Y}$ & $\mathrm{Y}$ & $\mathrm{Y}$ & $\mathrm{Y}$ & $\mathrm{Y}$ & $\mathrm{Y}$ & $\mathrm{Y}$ & $\mathrm{Y}$ \\
\hline Miralles ,1991 & $\mathrm{N}$ & $\mathrm{Y}$ & $\mathrm{Y}$ & $\mathrm{Y}$ & $\mathrm{Y}$ & $\mathrm{Y}$ & $\mathrm{N}$ & $\mathrm{N}$ & $\mathrm{Y}$ \\
\hline Yu, 2007 & $\mathrm{~N}$ & $\mathrm{Y}$ & $\mathrm{Y}$ & $\mathrm{Y}$ & $\mathrm{Y}$ & $\mathrm{Y}$ & Y & $\mathrm{Y}$ & $\mathrm{Y}$ \\
\hline Qingyi, 2002 & $\mathrm{~N}$ & $\mathrm{Y}$ & $\mathrm{Y}$ & $\mathrm{Y}$ & $\mathrm{Y}$ & $\mathrm{Y}$ & Y & $\mathrm{N}$ & $\mathrm{Y}$ \\
\hline Yin, 2016 & $\mathrm{~N}$ & $\mathrm{Y}$ & $\mathrm{Y}$ & $\mathrm{Y}$ & $\mathrm{Y}$ & $\mathrm{Y}$ & Y & $\mathrm{N}$ & $\mathrm{Y}$ \\
\hline DELL, 2013 & $\mathrm{~N}$ & Y & Y & Y & Y & Y & $\mathrm{Y}$ & Y & Y \\
\hline Barnes, 2014 & $\mathrm{~N}$ & $\mathrm{Y}$ & $\mathrm{Y}$ & $\mathrm{Y}$ & $\mathrm{Y}$ & $\mathrm{Y}$ & Y & $\mathrm{Y}$ & $\mathrm{Y}$ \\
\hline Andrew, 2008 & $\mathrm{~N}$ & $\mathrm{Y}$ & $\mathrm{Y}$ & $\mathrm{Y}$ & $\mathrm{Y}$ & $\mathrm{Y}$ & Y & $\mathrm{N}$ & $\mathrm{Y}$ \\
\hline Thomas, 2011 & $\mathrm{~N}$ & $\mathrm{Y}$ & $\mathrm{N}$ & $\mathrm{Y}$ & $\mathrm{Y}$ & $\mathrm{Y}$ & Y & $\mathrm{Y}$ & $\mathrm{Y}$ \\
\hline Kamiya, 2001 & $\mathrm{~N}$ & $\mathrm{Y}$ & $\mathrm{Y}$ & $\mathrm{Y}$ & $\mathrm{Y}$ & $\mathrm{Y}$ & Y & $\mathrm{Y}$ & $\mathrm{Y}$ \\
\hline Blondeau, 1990 & $\mathrm{Y}$ & $\mathrm{Y}$ & Y & $\mathrm{Y}$ & $\mathrm{Y}$ & $\mathrm{Y}$ & $\mathrm{N}$ & $\mathrm{Y}$ & $\mathrm{Y}$ \\
\hline Molina, 1990 & $\mathrm{~N}$ & Y & Y & Y & Y & Y & $\mathrm{Y}$ & $\mathrm{N}$ & Y \\
\hline Murphy, 1990 & $\mathrm{~N}$ & $\mathrm{Y}$ & $\mathrm{Y}$ & $\mathrm{Y}$ & $\mathrm{Y}$ & $\mathrm{Y}$ & $\mathrm{N}$ & $\mathrm{N}$ & $\mathrm{Y}$ \\
\hline Basso, 1997 & $\mathrm{~N}$ & Y & Y & Y & Y & Y & $\mathrm{Y}$ & Y & $\mathrm{Y}$ \\
\hline Centofanti, 1999 & $\mathrm{~N}$ & $\mathrm{Y}$ & $\mathrm{Y}$ & $\mathrm{Y}$ & $\mathrm{Y}$ & $\mathrm{Y}$ & Y & $\mathrm{Y}$ & $\mathrm{Y}$ \\
\hline Perchinsky,1997 & $\mathrm{N}$ & $\mathrm{Y}$ & $\mathrm{Y}$ & $\mathrm{Y}$ & $\mathrm{Y}$ & $\mathrm{Y}$ & Y & Y & $\mathrm{Y}$ \\
\hline Tschirkov, 1990 & $\mathrm{~N}$ & $\mathrm{Y}$ & $\mathrm{Y}$ & $\mathrm{Y}$ & $\mathrm{Y}$ & $\mathrm{Y}$ & $\mathrm{Y}$ & $\mathrm{Y}$ & $\mathrm{Y}$ \\
\hline Moosdoef, 1990 & $\mathrm{~N}$ & $\mathrm{Y}$ & $\mathrm{Y}$ & $\mathrm{Y}$ & $\mathrm{Y}$ & $\mathrm{Y}$ & Y & $\mathrm{Y}$ & $\mathrm{Y}$ \\
\hline Grande, 1993 & $\mathrm{~N}$ & $\mathrm{Y}$ & $\mathrm{Y}$ & $\mathrm{Y}$ & $\mathrm{Y}$ & $\mathrm{Y}$ & Y & $\mathrm{Y}$ & $\mathrm{Y}$ \\
\hline Dein, 1987 & $\mathrm{~N}$ & $\mathrm{Y}$ & $\mathrm{Y}$ & $\mathrm{Y}$ & $\mathrm{Y}$ & $\mathrm{Y}$ & $\mathrm{Y}$ & $\mathrm{Y}$ & $\mathrm{Y}$ \\
\hline Saraiva, 2016 & $\mathrm{~N}$ & $\mathrm{Y}$ & $\mathrm{Y}$ & $\mathrm{Y}$ & $\mathrm{Y}$ & $\mathrm{Y}$ & Y & $\mathrm{Y}$ & $\mathrm{Y}$ \\
\hline Ricardo, 2014 & $\mathrm{~N}$ & $\mathrm{Y}$ & $\mathrm{Y}$ & $\mathrm{Y}$ & $\mathrm{Y}$ & $\mathrm{Y}$ & Y & $\mathrm{Y}$ & $\mathrm{Y}$ \\
\hline Anna, 2011 & $\mathrm{~N}$ & $\mathrm{Y}$ & Y & $\mathrm{Y}$ & $\mathrm{Y}$ & $\mathrm{Y}$ & Y & $\mathrm{Y}$ & $\mathrm{Y}$ \\
\hline Massimo, 2012 & $\mathrm{~N}$ & $\mathrm{Y}$ & $\mathrm{Y}$ & $\mathrm{Y}$ & $\mathrm{Y}$ & $\mathrm{Y}$ & $\mathrm{Y}$ & $\mathrm{Y}$ & $\mathrm{Y}$ \\
\hline Faisal, 2003 & $\mathrm{~N}$ & $\mathrm{Y}$ & $\mathrm{Y}$ & $\mathrm{Y}$ & $\mathrm{Y}$ & $\mathrm{Y}$ & Y & $\mathrm{Y}$ & $\mathrm{Y}$ \\
\hline Bossert, 2005 & $\mathrm{~N}$ & $\mathrm{Y}$ & $\mathrm{Y}$ & $\mathrm{Y}$ & $\mathrm{Y}$ & $\mathrm{Y}$ & $\mathrm{Y}$ & $\mathrm{Y}$ & $\mathrm{Y}$ \\
\hline Patel, 2009 & $\mathrm{~N}$ & Y & Y & Y & Y & Y & $\mathrm{Y}$ & $\mathrm{Y}$ & $\mathrm{Y}$ \\
\hline Agarwal V, 2003 & $\mathrm{~N}$ & $\mathrm{Y}$ & Y & Y & Y & Y & $\mathrm{Y}$ & Y & $\mathrm{Y}$ \\
\hline Hoffmeier, 2005 & $\mathrm{~N}$ & $\mathrm{Y}$ & $\mathrm{Y}$ & $\mathrm{Y}$ & $\mathrm{Y}$ & $\mathrm{Y}$ & $\mathrm{Y}$ & $\mathrm{Y}$ & $\mathrm{Y}$ \\
\hline Dapper, 1988 & $\mathrm{~N}$ & $\mathrm{Y}$ & $\mathrm{Y}$ & $\mathrm{Y}$ & $\mathrm{Y}$ & $\mathrm{Y}$ & $\mathrm{N}$ & $\mathrm{N}$ & $\mathrm{Y}$ \\
\hline Thomas, 2007 & $\mathrm{~N}$ & $\mathrm{Y}$ & $\mathrm{Y}$ & $\mathrm{Y}$ & $\mathrm{Y}$ & $\mathrm{Y}$ & $\mathrm{Y}$ & $\mathrm{Y}$ & $\mathrm{Y}$ \\
\hline Thiene, 2013 & $\mathrm{~N}$ & $\mathrm{Y}$ & Y & $\mathrm{Y}$ & Y & $\mathrm{Y}$ & Y & $\mathrm{Y}$ & $\mathrm{Y}$ \\
\hline Agaimy, 2012 & $\mathrm{~N}$ & Y & Y & Y & $\mathrm{Y}$ & Y & $\mathrm{Y}$ & Y & Y \\
\hline Carrel, 2011 & $\mathrm{~N}$ & Y & Y & Y & Y & Y & $\mathrm{Y}$ & Y & $\mathrm{Y}$ \\
\hline Kumar, 2011 & $\mathrm{~N}$ & $\mathrm{Y}$ & $\mathrm{Y}$ & $\mathrm{Y}$ & $\mathrm{Y}$ & $\mathrm{Y}$ & Y & $\mathrm{Y}$ & $\mathrm{Y}$ \\
\hline Tazelaar 1992 & $\mathrm{~N}$ & $\mathrm{Y}$ & $\mathrm{Y}$ & $\mathrm{Y}$ & $\mathrm{Y}$ & $\mathrm{Y}$ & $\mathrm{Y}$ & $\mathrm{N}$ & Y \\
\hline
\end{tabular}




\section{Prevalence of PMCT}

The pooled prevalence of malignancies among the patients diagnosed with PCT was $9.9 \%$ (95\% CI,8.4\% to $11.4 \%)\left(\mathrm{I}^{2}=70 \% ; \mathrm{P}<0.001\right)$; similar results were determined from the cumulative meta-analysis (Figure 2). In addition, this prevalence had been basically stable since around 2003, according to the cumulative meta-analysis of all included studies (Figure 2). With the second period (1975 to 1980) as the reference, no differences in the malignancy odds were observed over the subsequent time periods. There were also no differences in the malignancy odds in relation to the study period ( $\leq 20$ years) and number of PCTs $(\leq 100)$ (Table 3$)$. With modeled prevalence of primary cardiac tumor malignancies, no time effect was observed from 1975 onward (Figure 3).

\section{DISCUSSION}

In this study, we report the prevalence and characteristics of PMCTs using data amassed over 6 decades from large, specialized, single-center studies. We confirm the rarity and lethality of PMCTs and offer insight into their epidemiology. The data from 38 retrospective studies over similar time periods were pooled, and our results suggest that the prevalence of primary cardiac tumor malignancies has remained stable over time.

To our knowledge, the first human diagnosis of primary cardiac malignancy was reported in 1934; it was

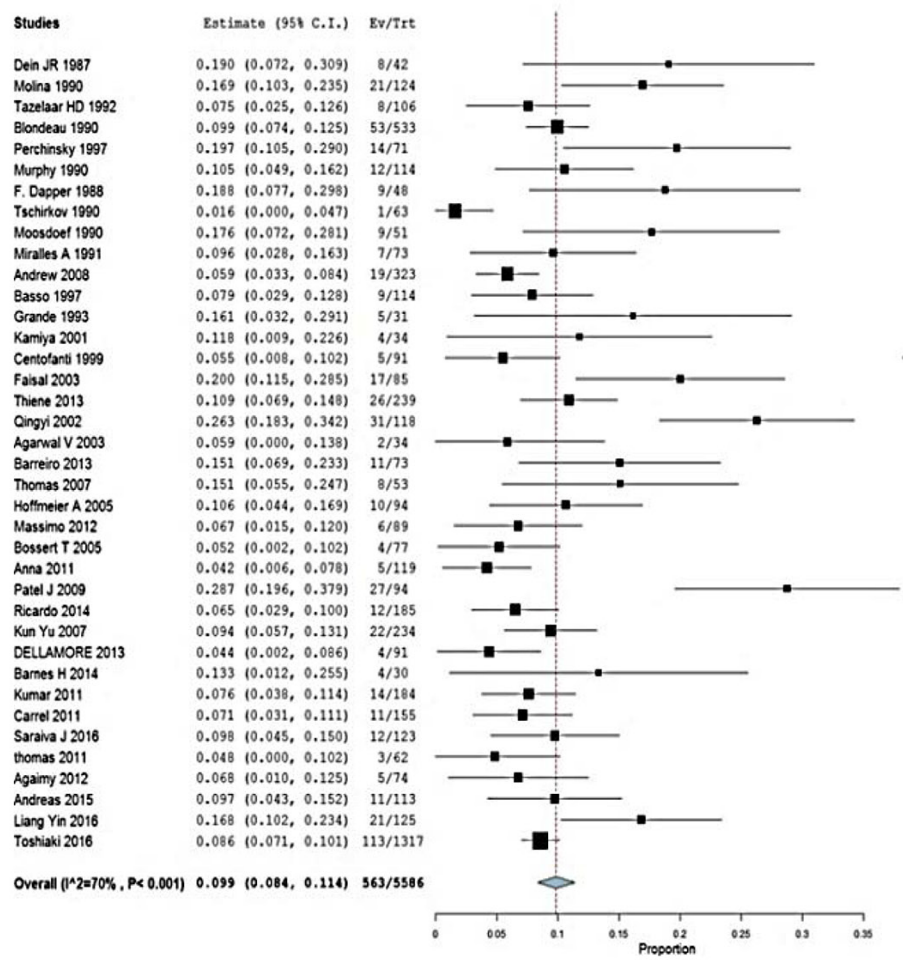

based on an electrocardiogram and biopsy of a peripheral embolic lesion [51]. As a result of the rarity of primary cardiac tumor occurrence, histological diversity, and the unique nature of heart anatomy, there have been few reports describing the epidemiology, presentation, and outcome after medical and surgical treatment [25]. Over the past several decades, our understanding of malignant cardiac tumors has gradually deepened owing to the available data from autopsy studies, case reports, and in recent years, from large, specialized, single-center studies [12]. Unless they obstruct intracardial flow or interfere with heart valve activity or the conduction system, cardiac neoplasms can remain clinically silent until they reach an advanced stage [52].

However, many of the tumors discovered during autopsy may have been incidentalomas rather than clinically significant tumors. For example, the SEER study showed that clinically apparent PMCTs have an estimated prevalence of 34 cases per 100 million persons, which is more than 100 times lower than the previous estimates from autopsy studies [7]. This study was based on clinical data; the prevalence of different cardiac tumors in this study was markedly different from that reported by the autopsy studies. Furthermore, the available data collected from surgery centers are more reliable than autopsy reports in estimating the prevalence of patients diagnosed with malignancies of primary cardiac tumors.

In 2010, Castillo and Silvay [12] reported that approximately one-quarter of all primary heart tumors are

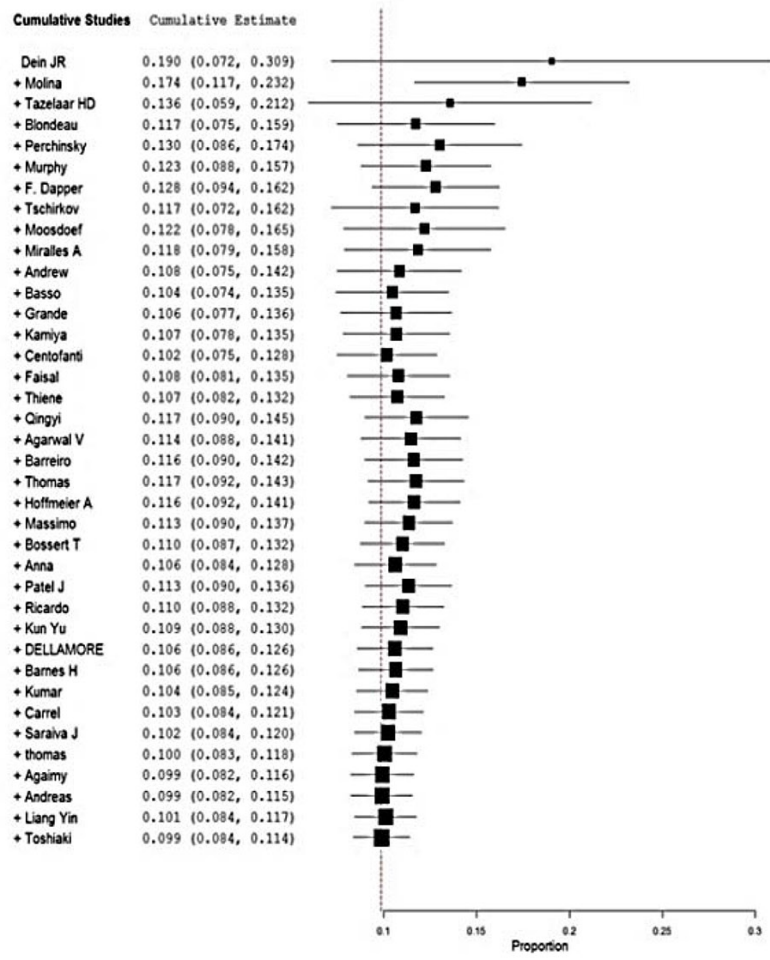

Figure 2: Forest plot depicting the prevalence of primary cardiac tumor malignancies. (A) Random-effects meta-analysis model and (B) cumulative meta-analysis model. 
Table 3: Regression model investigating the predictors of logit prevalence of PCT malignancies

\begin{tabular}{|c|c|c|c|c|c|}
\hline & Independent variable & MOR & $95 \% \mathrm{CI}$ & $\mathbf{P}$ & $\mathbf{I}^{2}$ \\
\hline \multirow[t]{9}{*}{ Period } & & & & & $70.40 \%$ \\
\hline & Before 1975 & 1.03 & 0.94 to 1.13 & 0.508 & \\
\hline & $1975-1980$ & 1 & & & \\
\hline & 1981-1985 & 0.99 & 0.91 to 1.07 & 0.766 & \\
\hline & 1986-1990 & 1.02 & 0.94 to 1.10 & 0.706 & \\
\hline & 1991-1995 & 1.05 & 0.97 to 1.15 & 0.226 & \\
\hline & $1996-2000$ & 0.98 & 0.92 to 1.05 & 0.572 & \\
\hline & $2001-2005$ & 0.97 & 0.91 to 1.05 & 0.474 & \\
\hline & After 2005 & 1.01 & 0.93 to 1.10 & 0.829 & \\
\hline \multirow[t]{3}{*}{ Study Period } & & & & & $70.96 \%$ \\
\hline & $\leq 20$ years & 1 & & & \\
\hline & $>20$ years & 0.99 & 0.96 to 1.04 & 0.993 & \\
\hline \multirow[t]{3}{*}{ Number of PCTs } & & & & & $70.70 \%$ \\
\hline & $\leq 100$ & 1 & & & \\
\hline & $>100$ & 0.99 & 0.95 to 1.03 & 0.637 & \\
\hline
\end{tabular}

MOR: malignancy odds ratio; PCTs: primary cardiac tumors (relative malignancy odds of PCTs per unit increase in each predictor).

malignant according to clinical data, but available data from single-center studies vary, and the reported prevalence is unstable, which was confirmed in our report [12]. Our study determined that the prevalence of malignant PCTs has remained stable in the past few decades, but the incidence of patients diagnosed with primary malignant cardiac tumors (PMCTs) has been reported to be increased by a lot in the past few decades. The observed increase in incidence may be confined to a specific country or region, which is unlikely to accurately reflect the incidence on a population level. This also suggests that the recently observed increase in incidence of PMCT most likely reflects increased diagnostic detection over time. However, the increasing number of patients diagnosed with PCT is

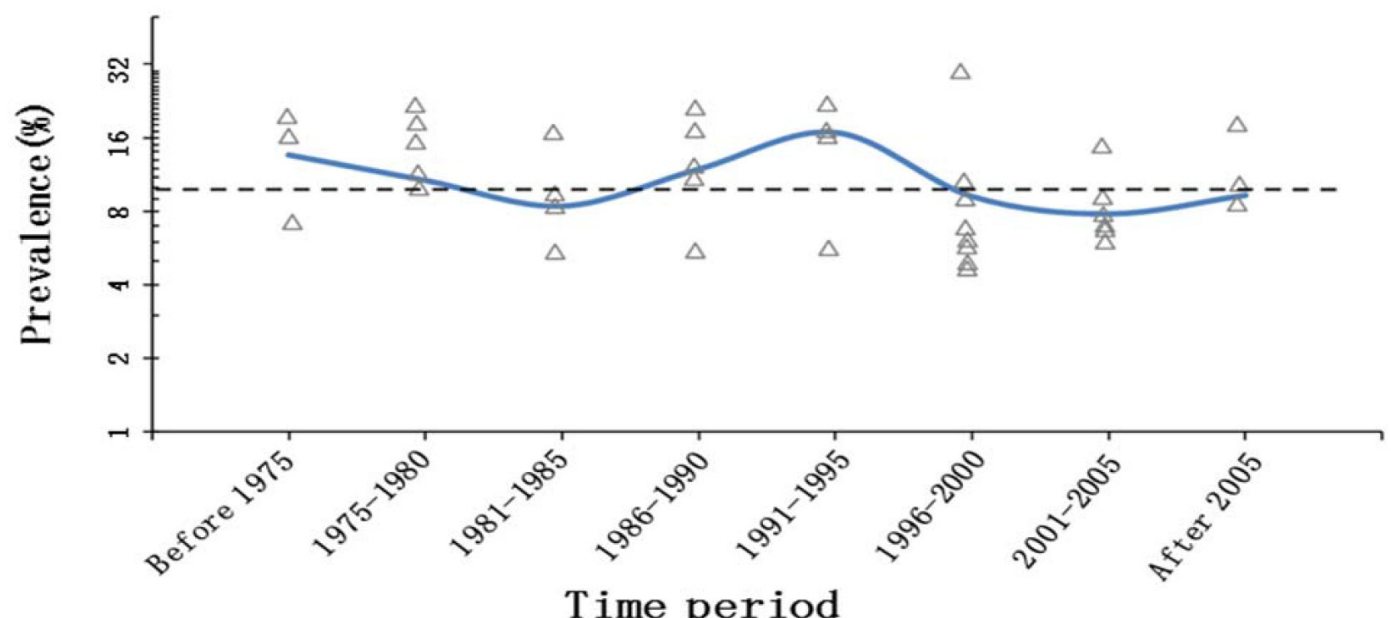

Figure 3: Modeled prevalence of primary cardiac tumor malignancies over time (pooled prevalence of each time period as knots). The dashed lines represent the overall prevalence of primary cardiac tumor malignancies. The y-axis is logit, and the labeled prevalence (percentage) increases are much larger in the upper part of the scale. 
another possibility, which requires further study. Better survival was observed for patients diagnosed with PMCT who underwent complete surgical resection compared with patients who did not in several early studies but failed to reach statistical significance [53]. Malignant neoplasms and primary malignant cardiac tumors usually require multiple modalities of treatment. Based on the literature we have incorporated into this study, complete tumor resection, adjuvant chemo- and/or radiotherapy, palliative strategy, and even heart transplant were included as therapies [16, $37,38,43,45]$, but the median survival of PMCT patients was less than 1 year, and this finding is consistent with previous studies that have documented survivals periods of 16.5 months and 9.6 months $[26,54]$. Randomized clinical trials have not been carried out to determine the optimal therapy for these primary malignancies [12].

The limitation of our research is that due to the nature of a retrospective study, the prognosis of cardiac tumors and the longitudinal changes could not be fully assessed. Another limitation was missing data regarding the methods and the prevalence of cancer stratified by age and other factors. Our research was based on clinical data, and the patients who were not diagnosed with PMCT at the time of death are missing from our data set, which prevents the data from being reflective of the general population.

In conclusion, this study confirms the rarity and lethality of primary malignant cardiac tumors and confirms that the malignancy rate has not increased over the past several decades. It is likely that the increasing incidence of patients diagnosed with primary malignant cardiac tumor is related to improvements in cardiac imaging tools (echocardiography, magnetic resonance imaging (MRI) and multi-detector computerized tomography (MDCT)) and improvements in diagnostic technology. Additional advances should be made in diagnostic technology as well as medical records and database facilities. We look forward to seeing randomized clinical trials examining the optimal therapy for primary malignant cardiac tumors, comprehensive and in-depth understanding of these malignancies as well as the consequent benefits for the patients.

\section{MATERIALS AND METHODS}

\section{Search strategy and selection criteria}

PubMed, EMBASE, and Web of Science were searched for relevant studies. Searches were limited to human studies and English-language publications using the following key words: "primary cardiac tumors or tumors of the heart", "surgical" and "experience". To avoid missing relevant studies, references of the retrieved studies were also screened. Citation lists of the retrieved articles were manually screened to ensure sensitivity of the search strategy. Data from case reports or autopsy studies were excluded. Studies with overlapping research periods and departments were excluded. Studies in which data were limited to single malignant, benign, extracardiac and secondary cardiac tumors as well as studies involving fewer than 30 patients diagnosed with PCTs were also excluded. Two authors independently assessed studies for inclusion, and discrepancies were resolved by consensus.

\section{Study selection and data extraction}

Data collection from the qualifying studies was independently performed by two authors (Shuai He and Li Yin). Two other investigators (Wei Qin and Zhibing Qiu) resolved any disagreements regarding the extraction of data. The following details were extracted from the eligible studies: authors; publication year; study period; study population characteristics (mean age, sex proportion, country and institution, and number of patients diagnosed with PCTs and PMCTs); and outcome (mortality or mean survival after surgical resection). Because the included studies were conducted over a range of dates, the median year of each study period was considered the time at which studies were performed.

\section{Quality assessment}

A new risk of bias table was used to assess study quality. The tool lists common safeguards used to assess the studies; they were typically easy to apply and demonstrated high interrater agreement. The higher the number of safeguards present, the more accurate the calculation of prevalence of primary cardiac tumor malignancies. We performed nine safeguards, which included both internal and external validity items for each study. Although the included studies did not focus solely on the prevalence of PMCT, this risk of bias tool was still very applicable for quality assessment of those studies.

\section{Statistical analysis}

A random-effects meta-analysis model and a cumulative meta-analysis model were used to evaluate the pooled prevalence and the trend of dynamic changes in PCT malignancies. We used the $\mathrm{I}^{2}$ to evaluate heterogeneity across studies; $\mathrm{I}^{2}>50 \%$ correlated with high heterogeneity. A regression analysis model was used to gain additional insight into the time trend of the clinically based PMCT prevalence; the association of logit prevalence with year and other important variables that were defined as a priori was analyzed, including the period when the studies were performed (before 1975, 1975 to 1980,1981 to 1985,1986 to 1990,1991 to 1995 , 1996-2000, 2001-2005, and after 2005), the original period of each study ( $\leq 20$ years and $>20$ years), and the number of PCTs included in each study $(\leq 100$ and $>100)$. Pooled analyses were conducted using OpenMeta-Analyst (AHRQ, grant number: R01HS018574), and the regression models were run using Stata SE version 12 (Stata Corp, College Station, TX). 


\section{Author contributions}

HS and QZB contributed to the study conception and design. QW and $\mathrm{CW}$ contributed to the collection and assembly of data. QZB and TSW contributed to the data analysis and interpretation. HS and YL contributed to writing the manuscript. All authors approved the final manuscript.

\section{CONFLICTS OF INTEREST}

The authors declare no conflicts of interest.

\section{REFERENCES}

1. Burke A. Primary malignant cardiac tumors. Semin Diagn Pathol. 2008; 25: 39-46.

2. Blondeau P. Primary cardiac tumors-French studies of 533 cases. Thorac Cardiovasc Surg. 1990; 38: 192-5. doi: 10.1055/s-2007-1014065.

3. Burke AP, Cowan D, Virmani R. Primary sarcomas of the heart. Cancer. 1992; 69: 387-95.

4. Moosdorf R, Scheld HH, Hehrlein FW. Tumors of the heart. Experiences at the Giessen University Clinic. Thorac Cardiovasc Surg. 1990; 38: 208-10. doi: 10.1055/s-2007-1014069.

5. Basso C, Valente M, Thiene G. Cardiac tumor pathology. Humana Press; 2013.

6. Araoz PA, Mulvagh SL, Tazelaar HD, Julsrud PR, Breen JF. CT and MR imaging of benign primary cardiac neoplasms with echocardiographic correlation. Radiographics. 2000; 20: 1303-19. doi: 10.1148/radiogra phics.20.5.g00se121303.

7. Oliveira GH, Al-Kindi SG, Hoimes C, Park SJ. Characteristics and Survival of Malignant Cardiac Tumors: a 40-year analysis of $>500$ patients Circulation. 2015; 132: 2395-402. doi: 10.1161/circulationaha.115.016418.

8. Cresti A, Chiavarelli M, Glauber M, Tanganelli P, Scalese M, Cesareo F, Guerrini F, Capati E, Focardi M, Severi $\mathrm{S}$. Incidence rate of primary cardiac tumors: a 14-year population study. J Cardiovasc Med (Hagerstown). 2016; 17: 37-43. doi: 10.2459/JCM.00000000000000059.

9. O'Donnell DH, Abbara S, Chaithiraphan V, Yared K, Killeen RP, Cury RC, Dodd JD. Cardiac tumors: optimal cardiac MR sequences and spectrum of imaging appearances. AJR Am J Roentgenol. 2009; 193: 377-87. doi: 10.2214/AJR.08.1895.

10. Plana JC. Added value of real-time three-dimensional echocardiography in assessing cardiac masses. Curr Cardiol Rep. 2009; 11: 205-9.

11. Salanitri J, Lisle D, Rigsby C, Slaughter R, Edelman R. Benign cardiac tumours: cardiac CT and MRI imaging appearances. J Med Imaging Radiat Oncol. 2008; 52: 5508. doi: 10.1111/j.1440-1673.2008.02010.x.
12. Burazor I, Aviel-Ronen S, Imazio M, Markel G, Grossman Y, Yosepovich A, Adler Y. Primary malignancies of the heart and pericardium. Clin Cardiol. 2014; 37: 582-8. doi: 10.1002/clc.22295.

13. McAllister HA Jr. Primary tumors and cysts of the heart and pericardium. Curr Probl Cardiol. 1979; 4: 1-51.

14. Karlof E, Salzberg SP, Anyanwu AC, Steinbock B, Filsoufi F. How fast does an atrial myxoma grow? Ann Thorac Surg. 2006; 82: 1510-2. doi: 10.1016/j.athoracsur.2005.11.014.

15. Roberts WC. Primary and secondary neoplasms of the heart. Am J Cardiol. 1997; 80: 671-82.

16. Isogai $T$, Yasunaga $H$, Matsui $H$, Tanaka $H$, Hisagi M, Fushimi K. Factors affecting in-hospital mortality and likelihood of undergoing surgical resection in patients with primary cardiac tumors. J Cardiol. 2016. doi: 10.1016/j. jjcc.2016.05.008.

17. Dein JR, Frist WH, Stinson EB, Miller DC, Baldwin JC, Oyer PE, Jamieson S, Mitchell RS, Shumway NE. Primary cardiac neoplasms. Early and late results of surgical treatment in 42 patients. J Thorac Cardiovasc Surg. 1987; 93: 502-11.

18. Molina JE, Edwards JE, Ward HB. Primary cardiac tumors: experience at the University of Minnesota. Thorac Cardiovasc Surg. 1990; 38: 183-91. doi: 10.1055/s-2007-1014064.

19. Tazelaar HD, Locke TJ, McGregor CG. Pathology of surgically excised primary cardiac tumors. Mayo Clin Proc. 1992; 67: 957-65.

20. Perchinsky MJ, Lichtenstein SV, Tyers GF. Primary cardiac tumors: forty years' experience with 71 patients. Cancer. 1997; 79: 1809-15.

21. Murphy MC, Sweeney MS, Putnam JB Jr, Walker WE, Frazier OH, Ott DA, Cooley DA. Surgical treatment of cardiac tumors: a 25-year experience. Ann Thorac Surg. 1990; 49: 612-7; discussion 7-8.

22. Dapper F, Gorlach G, Hoffmann C, Fitz H, Marck P, Scheld HH. Primary cardiac tumors - clinical experiences and late results in 48 patients. Thorac Cardiovasc Surg. 1988; 36: 80-5. doi: 10.1055/s-2007-1020049.

23. Tschirkov A, Michev B, Topalov V, Michailov D, Jurukova $\mathrm{Z}$, Petkov R. Incidences and surgical aspects of cardiac myxomas in Bulgaria. Thorac Cardiovasc Surg. 1990; 38: 196-200. doi: 10.1055/s-2007-1014066.

24. Miralles A, Bracamonte L, Soncul H, del Castillo RD, Akhtar R, Bors V, Pavie A, Gandjbackhch I, Cabrol C. Cardiac tumors: clinical experience and surgical results in 74 patients. Ann Thorac Surg. 1991; 52: 886-95. doi: 10.1016/0003-4975(91)91241-m.

25. Elbardissi AW, Dearani JA, Daly RC, Mullany CJ, Orszulak TA, Puga FJ, Schaff HV. Survival after resection of primary cardiac tumors: a 48-year experience. Circulation. 2008; 118: S7-S15. doi: 10.1161/ circulationaha.107.783126. 
26. Basso C, Valente M, Poletti A, Casarotto D, Thiene G. Surgical pathology of primary cardiac and pericardial tumors. Eur J Cardiothorac Surg. 1997; 12: 730-8.

27. Grande AM, Ragni T, Viganò M. Primary cardiac tumors. A clinical experience of 12 years. Tex Heart Inst J. 1993; 20: 223-30.

28. Kamiya H, Yasuda T, Nagamine H, Sakakibara N, Nishida S, Kawasuji M, Watanabe G. Surgical treatment of primary cardiac tumors: 28 years' experience in Kanazawa University Hospital. Jpn Circ J. 2001; 65: 315-9.

29. Centofanti P, Rosa ED, Deorsola L, Dato GM, Patanè F, Torre ML, Barbato L, Verzini A, Fortunato G, Summa MD. Primary cardiac tumors: early and late results of surgical treatment in 91 patients. Ann Thorac Surg. 1999; 68: 1236-41.

30. Bakaeen FG, Reardon MJ, Coselli JS, Miller CC, Howell JF, Lawrie GM, Espada R, Ramchandani MK, Noon GP, Weilbaecher DG. Surgical outcome in 85 patients with primary cardiac tumors. American Journal of Surgery. 2003; 186: 641-7.

31. Meng Q, Hong L, Lima J, Tong W, Qian Y, Lai S. Echocardiographic and pathologic characteristics of primary cardiac tumors: a study of 149 cases. Int J Cardiol. 2002; 84: 69-75.

32. Agarwal V, Agarwal SK, Srivastava AK, Kapoor S. Primary cardiac tumors: surgical experience and follow-up. Indian Heart J. 2003; 55: 632-6.

33. Barreiro M, Renilla A, Jimenez JM, Martin M, Al Musa T, Garcia L, Barriales V. Primary cardiac tumors: 32 years of experience from a Spanish tertiary surgical center. Cardiovasc Pathol. 2013; 22: 424-7. doi: 10.1016/j. carpath.2013.04.006

34. Thomas-de-Montpréville V, Nottin R, Dulmet E, Serraf A. Heart tumors in children and adults: clinicopathological study of 59 patients from a surgical center. Cardiovasc Pathol. 2007; 16: 22-8. doi: 10.1016/j. carpath.2006.05.008.

35. Hoffmeier A, Schmid C, Deiters S, Drees G, Rothenburger M, Tjan TD, Schmidt C, Löher A, Maintz D, Spieker T. Neoplastic heart disease - the Muenster experience with 108 patients. Thorac Cardiovasc Surg. 2005; 53: 1-8.

36. Padalino MA, Vida VL, Boccuzzo G, Tonello M, Sarris GE, Berggren H, Comas JV, Di Carlo D, Di Donato RM, Ebels T, Hraska V, Jacobs JP, Gaynor JW, et al. Surgery for primary cardiac tumors in children: early and late results in a multicenter European Congenital Heart Surgeons Association study. Circulation. 2012; 126: 22-30. doi: 10.1161/ circulationaha.111.037226.

37. Bossert T. Surgical experience with 77 primary cardiac tumors. Interact Cardiovasc Thorac Surg. 2005; 4: 311-5. doi: 10.1510/icvts.2004.103044.

38. Kośmider A, Jaszewski R, Marcinkiewicz A, Bartczak K, Knopik J, Ostrowski S. 23-year experience on diagnosis and surgical treatment of benign and malignant cardiac tumors. Arch Med Sci. 2013; 5: 826-30. doi: 10.5114/ aoms.2013.38677.

39. Patel J, Sheppard MN. Pathological study of primary cardiac and pericardial tumours in a specialist UK Centre: surgical and autopsy series. Cardiovasc Pathol. 2010; 19: 343-52. doi: 10.1016/j.carpath.2009.07.005.

40. Dias RR, Fernandes F, Ramires FJ, Mady C, Albuquerque CP, Jatene FB. Mortality and embolic potential of cardiac tumors. Arq Bras Cardiol. 2014; 103: 13-8. doi: 10.5935/ abc.20140096

41. Yu K, Liu Y, Wang H, Hu S, Long C. Epidemiological and pathological characteristics of cardiac tumors: a clinical study of 242 cases. Interact Cardiovasc Thorac Surg. 2007; 6: 636-9. doi: 10.1510/icvts.2007.156554.

42. Dell'amore A, Albertini A, Lamarra M. Twenty years experience in oncologic surgery for primary cardiac tumors. IL G Chir. 2013; 34: 106-11.

43. Barnes $H$, Conaglen $P$, Russell $P$, Newcomb A. Clinicopathological and surgical experience with primary cardiac tumors. Asian Cardiovasc Thorac Ann. 2014; 22: 1054-8. doi: 10.1177/0218492314528922.

44. Kumar N, Agarwal S, Ahuja A, Das P, Airon B, Ray R. Spectrum of cardiac tumors excluding myxoma: experience of a tertiary center with review of the literature. Pathol Res Pract. 2011; 207: 769-74. doi: 10.1016/j.prp.2011.09.014.

45. Carrel T, Erdös G, Eberle B, Englberger L, Pfammatter JP, Schmidli J, Kadner A, Stalder M. Surgical treatment of cardiac tumors - an overview and presentation of interesting cases. Cardiovasc Med. 2011; 14: 242-257.

46. Fragata J. [Primary malignant cardiac tumors: surgical results]. [Article in Portuguese]. Rev Port Cardiol. 2016; 35: 205-6.

47. Strecker T, Rösch J, Weyand M, Agaimy A. Primary and metastatic cardiac tumors: imaging characteristics, surgical treatment, and histopathological spectrum: a 10-yearexperience at a German heart center. Cardiovascular Pathology. 2012; 21: 436-43.

48. Agaimy A, Rösch J, Weyand M, Strecker T. Primary and metastatic cardiac sarcomas: a 12-year experience at a German heart center. Int J Clin Exp Pathol. 2012; 5: 928-38.

49. Habertheuer A, Laufer G, Wiedemann D, Andreas M, Ehrlich M, Rath C, Kocher A. Primary cardiac tumors on the verge of oblivion: a European experience over 15 years. J Cardiothorac Surg. 2015; 10: 56; 10. doi: 10.1186/ s13019-015-0255-4.

50. Yin L, He D, Shen H, Ling X, Li W, Xue Q, Wang Z. Surgical treatment of cardiac tumors: a 5-year experience from a single cardiac center. J Thorac Dis. 2016; 8: 911-9. doi: 10.21037/jtd.2016.03.87.

51. Barnes AR, Beaver DC, Snell AM. Primary sarcoma of the heart: Report of a case with electrocardiographic and pathological studies. Am Heart J. 1934; 9: 480-91.

52. Hirota J, Akiyama K, Taniyasu N, Maisawa K, Kobayashi Y, Sakamoto N, Komatsu N. Injury to the tricuspid valve 
and membranous atrioventricular septum caused by huge calcified right ventricular myxoma: report of a case. Circulation Journal. 2004; 68: 799-801.

53. Putnam JB Jr, Sweeney MS, Colon R, Lanza LA, Frazier $\mathrm{OH}$, Cooley DA. Primary cardiac sarcomas. Ann Thorac Surg. 1991;51:906-10.
54. Donsbeck AV, Ranchere D, Coindre JM, Le Gall F, Cordier JF, Loire R. Primary cardiac sarcomas: an immunohistochemical and grading study with long-term follow-up of 24 cases. Histopathology. 1999; 34: 295-304. 